\title{
The Disorderly Infiltration of EU Law in Civil Procedure
}

\author{
Thalia Kruger ${ }^{1,2}$
}

(C) T.M.C. Asser Press 2016

\begin{abstract}
Since 1968 the European Union (or the European Economic Community as it then was) has legislated in the field of civil procedure. These rules do not replace domestic laws and codes of civil procedure, but gradually take over aspects in the field: it infiltrates. The purpose of this article is to show that this infiltration is chaotic rather than logical. It discusses certain aspects of the scope of EU legislation in the field of civil procedure, provisional measures, the recognition and enforcement of foreign judgments and systemic hurdles for a more logical delineation between the EU and domestic spheres of the law. It shows the disorderly infiltration without offering a definite solution, taking the view that such disorderliness is inescapable in light of the current state of EU law on civil procedure and political realities.
\end{abstract}

Keywords International civil procedure - European civil procedure - EU law · Jurisdiction · Exequatur · Enforcement · Brussels I Regulation (Regulation 44/2001) · Brussels I bis Regulation (Regulation 1215/2012) · Brussels II bis Regulation (Regulation 2201/2003) - Maintenance Regulation (Regulation 4/2009) Succession Regulation (Regulation 650/2012)

\section{Introduction}

The Brussels Convention was revolutionary in 1968 when its first version was concluded. It was a multilateral convention on the recognition and enforcement of judgments, but it also included uniform rules on jurisdiction. An almost complete

Thalia Kruger

thalia.kruger@uantwerp.be

1 Personal Rights and Property Rights Research Group, Faculty of Law, University of Antwerp,

23 Venus Street, 2000 Antwerp, Belgium

2 University of Cape Town, Cape Town, South Africa 
double convention (containing not only rules on recognition and enforcement, but also on jurisdiction) was innovative at the time. ${ }^{1}$ The rationale behind the choice for a double convention was that uniform jurisdiction rules would facilitate recognition and enforcement. It is more palatable to grant easy enforcement to a foreign judgment if there is a guarantee that the foreign court has based its jurisdiction on acceptable grounds, agreed by all States in the club (the 'club' being the European Economic Community at the time, now the European Union (EU)).

Of course EU law is continuously moving forward, towards more legislation, and this also holds true for the Brussels regime. A part of this evolution is the subject of a recent article in this Journal by Xandra Kramer. ${ }^{2}$ Yet, moving forward is often hampered (or delayed) by the search for compromise at the negotiation table. The European Commission's eagerness to move forward ${ }^{3}$ combined with the need to compromise on some points often results in a badly delineated end-product. The newly created EU legislation interacts with national law in a complex manner. The complexity of the interaction is particularly clear in the field of civil procedure. Domestic rules of civil procedure are detailed, regulating various steps in different types of procedures and the division of tasks between different authorities.

These systems have been in existence for as long as States have had functional justice systems, i.e. long before the EU embarked on legislative initiatives in this area. EU legislation, since the Brussels Convention in 1968, is infiltrating these comprehensive domestic systems of civil procedure. Legislating certain aspects on an EU scale is efficient. A fine example is the recognition and enforcement of judgments: regulating this on the EU level and thus imposing mutual obligations on Member States makes sense and better ensures common results than leaving the issue to national legislatures. Yet, other (related) aspects, such as actual enforcement through the attachment of assets in bank accounts or the selling of property in order to pay debts, are best left to domestic law.

The exact division of where EU legislation is efficient and where regulation is best left to the domestic level is not a simple question. Increasing EU legislation does not take the form of concentric circles spreading its sphere gradually. This is why I have chosen the image of infiltration. The infiltration has been unsystematic. ${ }^{4}$ It has become increasingly difficult to draw clear borders between aspects that fall under EU law and those that are subject to domestic legislation.

\footnotetext{
1 See also Baumgartner (2012), p. 570.

2 Kramer (2013).

3 See the Conclusions of the European Council at Tampere (15 and 16 October 1999); the Hague Programme (Council Conclusions of 4 and 5 November 2004) and the Hague Programme: 10 priorities for the next 5 years, $\operatorname{COM}(2005)$ 184, OJ C 236, 24 September 2005; the Stockholm Programme (Council Conclusions of 10 and 11 December 2009) and the Action Plan Implementing the Stockholm Programme of 20 April 2010, $\operatorname{COM}(2010)$ 171; the Conclusions of the European Council (26 and 27 June 2014).

4 See Briggs (2013), who states at p. 46: 'Of course, the transitional phase is bound to be untidy, as transitional phases always are' and Clarkson and Hill (2011), who state at p. 6: 'It should be noted, however, that the European regimes are neither completely uniform nor comprehensive'.
} 
The purpose of this article is to discuss the partial infiltration in a few chosen fields, where it is most apparent. The new Brussels I bis Regulation ${ }^{5}$ forms the main focus, but the previous Brussels $\mathrm{I}^{6}$ and other regulations in the field of civil procedure (Brussels II bis, ${ }^{7}$ the Insolvency, ${ }^{8}$ Maintenance $^{9}$ and Succession ${ }^{10}$ Regulations, the Enforcement Order, ${ }^{11}$ the Payment Order, ${ }^{12}$ the Small Claims Procedure $^{13}$ the European Account Preservation Order ${ }^{14}$ and the Service ${ }^{15}$ and Evidence ${ }^{16}$ Regulations) will be included in the analysis, as they form interesting points of comparison.

It is not my aim to assess whether more or less infiltration is necessary. Rather, I wish to point out that the way in which the infiltration is happening is complex and often illogical. This makes life difficult for lawyers and judges who have to wade their way through the marshy maze that civil procedure has become.

In order to assess the current state of affairs, the article will discuss, first, certain aspects of the scope of EU legislation in the field of civil procedure, second,

${ }^{5}$ Regulation (EU) No. 1215/2012 of 12 December 2012 on jurisdiction and the recognition and
enforcement of judgments in civil and commercial matters (Recast), OJ L 351, 20 December 2012, p. 1.
6 Regulation (EC) No. 44/2001 of 22 December 2000 on jurisdiction and the recognition and
enforcement of judgments in civil and commercial matters, OJ L 012, 16 January 2001, p. 1.
7 Regulation (EC) No. 2201/2003 of 27 November 2003 concerning jurisdiction and the recognition and
enforcement of judgments in matrimonial matters and the matters of parental responsibility, OJ L 338, 23
December 2003, p. 1.
${ }^{8}$ Regulation (EC) No. 1346/2000 of 29 May 2000 on Insolvency Proceedings, OJ L 160, 30 June 2000, p. 1; Regulation (EU) No. 2015/848 of 20 May 2015 on Insolvency Proceedings (Recast), OJ L 141, 5 June 2015, p. 19.

9 Regulation (EC) No. 4/2009 of 18 December 2008 on jurisdiction, applicable law, recognition and enforcement of decisions and cooperation in matters relating to maintenance obligations, OJ L 7, 10 January 2009, p. 1.

${ }^{10}$ Regulation (EU) No. 650/2012 of 4 July 2012 on jurisdiction, applicable law, recognition and enforcement of decisions and acceptance and enforcement of authentic instruments in matters of succession and on the creation of a European Certificate of Succession, OJ L 201, 27 July 2012, p. 107.

11 Regulation (EC) No. 805/2004 of 21 April 2004 creating a European Enforcement Order for uncontested claims, OJ L 143, 30 April 2004, p. 15.

12 Regulation (EC) No. 1896/2006 of 12 December 2006 creating a European order for payment procedure, OJ L 399, 30 December 2006, p. 1. This Regulation has recently been amended by Regulation (EU) No. 2015/2421 of 16 December 2015 amending Regulation (EC) No. 861/2007 establishing a European Small Claims Procedure and Regulation (EC) No. 1896/2006 creating a European order for payment procedure, OJ L 341, 24 December 2015, p. 1. The amendments will take effect on 14 July 2017.

13 Regulation (EC) No. 861/2007 of 11 July 2007 establishing a European Small Claims Procedure, OJ L 199, 31 July 2007, p. 1. This Regulation has recently been amended by Regulation (EU) No. 2015/2421 of 16 December 2015 amending Regulation (EC) No. 861/2007 establishing a European Small Claims Procedure and Regulation (EC) No. 1896/2006 creating a European order for payment procedure, OJ L 341, 24 December 2015, p. 1. The amendments will take effect on 14 July 2017.

14 Regulation (EU) No. 655/2014 of 15 May 2014 establishing a European Account Preservation Order procedure to facilitate cross-border debt recovery in civil and commercial matters, OJ L 189, 27 June 2014, p. 59.

15 Regulation (EC) No. 1393/2007 of 13 November 2007 on the service in the Member States of judicial and extrajudicial documents in civil or commercial matters (service of documents), and repealing Council Regulation (EC) No. 1348/2000, OJ L 324, 10 December 2007, p. 79.

16 Council Regulation (EC) No. 1206/2001 of 28 May 2001 on cooperation between the courts of the Member States in the taking of evidence in civil or commercial matters, OJ L 174, 27 June 2001, p. 1. 
provisional measures and, third, recognition and enforcement. Lastly the article will turn to systemic hurdles for a more logical delineation between the EU and domestic spheres of the law.

\section{Scope of EU Rules on Civil Procedure}

Three aspects of the scope of the EU legislation on civil procedure are of interest for the current analysis: first, to which persons (claimants or defendants) does the legislation apply; second, the requirement of internationality for scope purposes; and third, which matters are included? I will now turn to each of these questions.

\subsection{Personal Scope of Application}

When a situation has elements both within and outside the EU, the Regulations follow very different approaches. We can divide the approaches into two broad categories: Regulations that harmonise jurisdiction rules only partially and those that have introduced unified jurisdiction rules.

The first category encompasses Brussels I bis, II bis and the Insolvency Regulation. The first step, in 1968, was to create harmonised rules of jurisdiction only for situations that are closely linked to the EU. Within this category, the approaches to determine the scope of application vary to a large extent. The Court of Justice EU has had quite some work in clarifying the scope of application of the Regulations. $^{17}$

Turning to the history of this delimitation, one sees that the Brussels Convention introduced an a-symmetric system with respect to third States. ${ }^{18}$ While jurisdiction over persons domiciled in third States is determined by the domestic law of the Member States (with certain exceptions ${ }^{19}$ ), all judgments of Member State courts benefit from the same easy recognition and enforcement regime under the Convention. This means that the exorbitant bases of jurisdiction, such as the nationality of the plaintiff, ${ }^{20}$ remain valid. What is worse is that the resulting judgment of a French court has effects not only in France, but throughout the EU. This particular a-symmetry of the Brussels I regime has been criticised since the 1960s, particularly by authors from the United States. ${ }^{21}$

Although the Brussels Convention and after it the Regulation were subjected to various amendments, this basic structure was never changed. The issue was an

\footnotetext{
${ }^{17}$ For Brussels I: CJEU Case C-412/98 Group Josi Reinsurance Company SA v. Universal General Insurance Company (UGIC) [2000] ECR I-5925; Case C-281/02 Owusu v. Jackson [2005] ECR I-1383. For Brussels II bis: CJEU Case C-68/07 Sundelind Lopez v. Lopez Lizazo [2007] ECR I-10403. For the Insolvency Regulation: CJEU Case C-328/12 Schmid v. Hertel, ECLI:EU:C:2014:6; Case C-295/13 H v. HK, ECLI:EU:C:2014:2410.

18 For a more in-depth discussion of these issues, see Kruger (2008); Nuyts and Watté (2005).

19 Exclusive bases of jurisdiction and forum clauses.

20 Art. 14 French Civil Code.

21 See, inter alia, Nadelmann (1967); von Mehren (1981); Baumgartner (2012), pp. 574 and 588; Franzina (2014).
} 
important one at the most recent amendment of the Regulation. In the initial proposal by the European Commission, the scope of the Regulation was extended to all third State defendants. ${ }^{22}$ The Proposal thus provided bases of jurisdiction for all international law suits in civil and commercial matters, and would replace the national (exorbitant) bases of jurisdiction. The jurisdictional bases for parties domiciled in the EU and those for parties domiciled in third States were not equal, but at least there was one source of law for all these cases. The issue solicited much debate. $^{23}$

In the end, only small remnants of the extension to third States survived the discussions in the Parliament and in the Council. ${ }^{24}$ While the Commission proposed a coherent system, the negotiations again led to piecemeal legislation. The practitioner now has to take into account four elements (instead of the previous three mentioned above) to figure out whether his or her case falls within the personal scope of the Regulation for purposes of determining the jurisdiction of the EU Member State courts ${ }^{25}$ :

1. Does the case fall within one of the bases of exclusive jurisdiction, such as those for immovable property or the validity of intellectual property? In this case the domiciles of the parties are irrelevant. ${ }^{26}$

2. Does the dispute concern an employment or consumer contract while the defendant or the consumer/employee plaintiff is domiciled in the EU? ${ }^{27}$ This situation is different from that of the previous versions of the Regulation and Conventions. Previously, this basis of jurisdiction applied only if the defendant was domiciled in the EU. If the plaintiff was domiciled in the EU and the defendant in a third State, jurisdiction would have to be determined according to the national bases of jurisdiction of each of the Member States. ${ }^{28}$

3. Have the parties concluded a forum clause in favour of a court in the EU? For this category the domicile of the parties is irrelevant as well. ${ }^{29}$ This is different from the position under the previous version of the Regulation and Conventions, where it was required that at least one of the parties is domiciled in the EU. $^{30}$

\footnotetext{
${ }^{22}$ See the Commission's Proposal for a Regulation of 14 December 2010 on jurisdiction and the recognition and enforcement of judgments in civil and commercial matters (Recast), $\operatorname{COM(2010)} 748$ and the Commission's Green Paper of 21 April 2009, COM(2009) 175. See also Borrás (2012); Franzina (2014).

${ }^{23}$ See for instance Borrás (2012); Layton (2012); Hausmann (2012), pp. 21-27. See also Nuyts's study on residual jurisdiction and the Hess/Pfeiffer/Schlosser Report of 2008 on the Brussels I Regulation (the Heidelberg Report).

${ }^{24}$ See the Report by the European Parliament, A7-0320/2012 of 15 October 2012.

${ }^{25}$ Nuyts and Watté (2005); Kruger (2008); Nuyts (2007).

${ }^{26}$ Art. 24 Brussels I bis.

27 Arts. 6, 18(1) and 21(1) Brussels I bis.

${ }^{28}$ Art. 4 of Brussels I (2001 version) did not provide an exception for consumer and employee plaintiffs in the EU.

29 Art. 25 Brussels I bis.

${ }^{30}$ See Art. 23 Brussels I (2001 version).
} 
4. For all other cases, is the defendant domiciled in the EU ${ }^{31}$ This general rule has itself remained unchanged, but its reach is of course influenced by the changes mentioned above.

The piecemeal approach is exacerbated by the Court of Justice of the EU's finding that the grounds of jurisdiction in the Regulation are compulsory. ${ }^{32}$ This means that if a court has jurisdiction on the basis of one of the grounds in the Regulation, it cannot decline such jurisdiction other than through the Regulation itself. This is particularly problematic if the parties had agreed to a forum outside the EU. If one of the parties subsequently acts against that bargain and brings the case to a court in the EU that has jurisdiction on one of the bases provided in the Regulation, that court must hear the case. It cannot send the parties away to respect their forum agreement, except if a higher international norm provides this possibility. Such a higher international norm is the Hague Choice of Court Convention of 2005. ${ }^{33}$ This Convention entered into force on 1 October $2015 .^{34}$ This means that there is an international solution. However, this Convention is only in force in the EU (all Member States except Denmark) and Mexico. Singapore and the United States have signed but not yet ratified the Convention. ${ }^{35}$ This means that forum clauses in favour of third States will most often not be respected. The courts of some Member States respect such clauses on the basis of their own civil procedure rules, which allow jurisdiction to be declined. ${ }^{36}$ However, this is not in line with the Regulation. The negotiators probably hoped to create an incentive for States to become a party to the Hague Choice of Court Convention. ${ }^{37}$ In this way States will at least have certainty that choice of court agreements in favour of their courts will be respected. It is a pity that this colonial thinking was permitted to trump good practice, respect and legal certainty in international litigation.

A similar problem can arise when a dispute has a particularly close connection to the courts of a third State while a court in a Member State has jurisdiction according to Brussels I bis. Then also the Member State court, if seised first, is incapable of declining its jurisdiction in favour of the court in the third State, as there is no such possibility in the Regulation. ${ }^{38}$

Parallel proceedings in courts of which one is in a Member State and the other in a third State could be added to the problem areas. Brussels I in the 2001 and all previous versions contained no possibility for Member State courts to decline jurisdiction. This has changed in Brussels I bis. This is one of the remnants of the Commission's bold plans. Member State courts are now explicitly permitted to

\footnotetext{
31 Arts. 4 and 6 Brussels I bis.

32 CJEU Case C-281/02 Owusu v. Jackson [2005] ECR I-1383. See also Francq (2014), pp. 113-117.

33 Full text available at the website of the Hague Conference on Private International Law: http://www. hcch.net/index_en.php?act=conventions.text\&cid=98.

34 See http://www.hcch.net/index_en.php?act=conventions.status2\&cid=98.

35 Ibid.

36 Layton (2012), p. 79.

37 Francq (2014), p. 109.

38 Layton (2012), p. 78.
} 
decline jurisdiction in favour of a third State court if the same action had been brought there first. ${ }^{39}$ The provision is filled with limitations, but it is an improvement compared to the prior gap in the legislation. The most important limitation is that this possibility of declining jurisdiction can only be used if the case was first brought in the third State. This follows the logic of the lis pendens rule between Member States, ${ }^{40}$ without any consideration of whether the third State court would follow such prior-in-time logic. While a rule is better than no rule at all, this lack of flexibility is disappointing. ${ }^{41}$ In the absence of any rule, Member State courts were not able to decline jurisdiction in favour of courts in third States if the jurisdiction had been based on the Regulation. ${ }^{42}$

In the sphere of the recognition and enforcement of foreign judgments, there is not, as yet, any EU legislation with respect to third States. A judgment issued by a third State can be recognised and enforced in a Member State only according to international conventions or national law. EU law does not regulate this issue. This is true for all the Regulations on jurisdiction and recognition and enforcement that have been enacted until now. Accordingly, there is no guarantee that a judgment that is enforceable in one Member State will also be enforceable in another Member State. $^{43}$

Brussels II bis requires a three-step reasoning: does the court in the EU that is seised have jurisdiction according to the Regulation's rules; if not, does another court in the EU have jurisdiction according to the Regulation's rules; if not, a court may look at its domestic bases of jurisdiction. ${ }^{44}$

The Insolvency Regulation applies whenever the centre of the debtor's interests is located in the EU. ${ }^{45}$ The Court of Justice has given a broad interpretation to the scope of the Regulation. It has ruled that when the centre of main interests (COMI) is in the EU, the Regulation also applies to a transaction that the debtor had concluded with a party domiciled in a third State and that the liquidator wishes to annul. ${ }^{46}$ The same is true for an action for reimbursement that the liquidator seeks to bring against a former managing director of the debtor company where the director is domiciled outside the EU. ${ }^{47}$

In the second category, Regulations include jurisdictional bases for all parties, irrespective of their domicile or habitual residence (e.g. the Maintenance and Succession Regulations). These Regulations have made all national rules

\footnotetext{
39 Art. 33 Brussels I bis. See also Franzina (2014), pp. 65-68.

40 Now in Art. 29 Brussels I bis.

41 See also Rogerson (2012), p. 119, stating that the fact that the rule applies only if the third State court was seised first is 'extremely regrettable and must be amended'.

42 This is an effect of the Owusu judgment. See also Rogerson (2012), p. 112. For an analysis of the situation and questions prior to the judgment, see Fentiman (2005).

43 See CJEU Case C-129/92 Owens Bank v. Bracco [1994] ECR I-117.

44 This is a result of Arts. 6 and 7 Brussels II bis, as clarified by the CJEU in Case C-68/07 Sundelind Lopez v. Lopez Lizazo [2007] ECR I-10403.

45 Art. 3 Insolvency Regulation 1346/2000 and Art. 3 Insolvency Regulation 2015/848.

46 CJEU Case C-328/12 Schmid v. Hertel, ECLI:EU:C:2014:6.

47 CJEU Case C-295/13 H v. HK, ECLI:EU:C:2014:2410.
} 
determining international jurisdiction redundant. They have thus allowed a full infiltration, replacing national rules on jurisdiction for international cases. While this approach brings clarity and the ease of application, it is politically not always feasible, as the recast of Brussels I showed.

\subsection{Requirement of Internationality}

The Regulations were created for a cross-border context. However, 'cross-border' or an 'international case' is not understood in the same way in the different regulations.

For Brussels I the Court of Justice found that a case which has a link to only one Member State and a State outside the EU is international for the purposes of that Regulation: the courts of the Member State in question are obliged to apply the Regulation. $^{48}$

For Brussels II bis, although the personal scope is quite different, as set out above, the Court of Justice came to a similar conclusion. Whenever a case has elements in different States, whether they are in the EU or not, a court in the EU must start by testing the application of Brussels II bis. ${ }^{49}$ In this particular case the defendant was resident in Cuba and had Cuban nationality. These elements do not exclude the application of the EU legislation.

The Court of Justice came to the same conclusion with respect to the Insolvency Regulation: if a case is linked to one Member State, where the debtor's COMI is situated, and a third State, the Regulation applies. ${ }^{50}$

The element of internationality is of particular importance for the uniform procedures that the EU legislator has created. The Small Claims Procedure and the Order for Payment have introduced uniform procedures that apply in all Member States except Denmark. ${ }^{51}$ These uniform procedures create autonomous steps to form an entire self-standing procedure. The Regulations govern the way in which the procedure is initiated, the elements that the judges must assess, the transfer of documents between the parties and the courts, appeals and review. They also determine that there is no need for a declaration of enforceability in any Member State. The result of the procedure is thus an EU order, which can circulate freely throughout the EU, without any need for exequatur.

The uniform procedures have not replaced national procedures with the same goals, but merely exist alongside them. These uniform procedures can only be applied in cross-border cases. ${ }^{52}$ Each national procedure defines its own scope of application and if a party falls within the scope of both a national and the EU procedure, he or she may choose which route to pursue.

\footnotetext{
48 CJEU Case C-281/02 Owusu v. Jackson [2005] ECR I-1383.

49 CJEU Case C-68/07 Sundelind Lopez v. Lopez Lizazo [2007] ECR I-10403.

50 CJEU Case C-328/12 Schmid v. Hertel, ECLI:EU:C:2014:6.

51 Recital 32 of the Order for Payment and Recital 38 of the Small Claims Procedure Regulation. The peculiar position of Denmark is discussed in the last section of this article (see Sect. 5.2 below).

52 Art. 2(1) Order for Payment Regulation and Art. 2(1) Small Claims Procedure Regulation. The new Regulation 2015/2421 amending these Regulations has not substantially changed these rules.
} 
'Cross-border' under these Regulations means that at least one of the parties has his or her domicile or habitual residence in an EU Member State other than that where the court is situated. ${ }^{53}$

The Account Preservation Order is a more limited uniform procedure: it only deals with preserving assets in bank accounts. ${ }^{54}$ This Regulation's application is also restricted to cross-border cases. ${ }^{55}$ However, for this Regulation 'cross-border' is not defined in exactly the same manner as under the other two uniform procedures. In the case of the Account Preservation Order, a cross-border order is one where the bank account is held in a State other than that of the court seized or of the domicile of the creditor. ${ }^{56}$

EU legislation has thus infiltrated quite extensively, but has remained mainly on the level of international civil procedure. Until now, the Regulations on civil procedure do not directly regulate domestic procedure. However, as will become apparent in the following sections of this article, regulating on the international level inadvertently but unassailably has an impact on domestic law.

\subsection{Material Scope: A Few Selected Aspects Including Arbitration}

On many occasions the material scope of the Regulations have been the subject of debate and not infrequently illogical limitations resulted from compromise.

Brussels II's scope was initially limited to divorce, marriage annulment and the parental responsibility for children of both spouses when this issue arose in the divorce or annulment proceedings. ${ }^{57}$ This limitation had the result that children of separating parents did not fall under the Regulation but under domestic rules of jurisdiction if their parents were not married. This strange delimitation was rectified by Brussels II bis, which applies to parental responsibility for all children irrespective of the marital status of their parents and irrespective of any link to divorce or marriage annulment proceedings. ${ }^{58}$

The Insolvency Regulation's illogical nature is situated in its exclusion of the insolvency of insurance undertakings, credit undertakings and certain investment undertakings. 59

The Commission's Proposal for the recast of Brussels $\mathrm{I}^{60}$ likewise contained some exclusions that were not based on a coherent delimitation. Two aspects, while still part of the Brussels I system, were excluded from the system of the abolition of exequatur. These were (1) violations of privacy and rights relating to personality

\footnotetext{
53 Arts. 2 and 3 Payment Order Regulation; Arts. 2 and 3 Small Claims Regulation.

54 The material scope of this Regulation is discussed in more detail in Sect. 2.3 below.

55 Art. 2 European Account Preservation Order Regulation.

56 Art. 3 European Account Preservation Order Regulation.

57 Art. 1(1) Brussels I Regulation (1347/2000, replaced by Brussels II bis).

58 Art. 1(1) and 1(2) Brussels II bis, as well as Recital 5 of this Regulation.

59 Art. 1(2) Insolvency Regulation 1346/2000; Art. 1(2) Insolvency Regulation 848/2015.

60 Proposal for a Regulation of the European Parliament and of the Council on jurisdiction and the recognition and enforcement of judgments in civil and commercial matters (Recast) of 14 December 2010, COM(2010) 748.
} 
(including defamation) and (2) compensation obtained in collective proceedings for unlawful business practices. ${ }^{61}$ These exclusions were not based on legal logic. ${ }^{62}$ They were removed during the negotiation process and the different dispensation for these two fields is not part of the final text. In contrast, the public policy exception was reinserted although the Commission had deleted it. ${ }^{63}$ In this case, the equilibrium of the infiltration was restored.

Another matter relating to scope which caused debate is the exclusion of arbitration from Brussels I ( bis). In its recast proposal, the Commission introduced a number of rules on arbitration, particularly on the interaction between court proceedings and arbitration. ${ }^{64}$ The Commission aimed to regulate parallel proceedings between litigation and arbitration. The purpose of the new rules is to provide Member State courts with a legal basis in Brussels I bis to decline jurisdiction. These amendments did not survive the negotiations. In the final text the total exclusion of arbitration was maintained. ${ }^{65}$ The Parliament's Legal Committee viewed the New York Convention ${ }^{66}$ as sufficient to regulate arbitration. ${ }^{67}$ A new Recital (12) explains the exclusion of arbitration.

Leaving arbitration entirely out of the EU system is a coherent choice. While some scholars have advocated the inclusion of arbitration in the Brussels I regime, ${ }^{68}$ this has long been a controversial matter. ${ }^{69}$ In my view, it is better for the EU legislator not to regulate this matter than to regulate it partially. It is true that the dividing line between court proceedings and arbitration is not always clear, ${ }^{70}$ for example where the parties have taken up an arbitration clause in their contract but one of the parties institutes proceedings in a court of a Member State. In such situation, the Court of Justice has ruled that the Member State court is not permitted to grant an anti-suit injunction. The substance of the matter does fall within the scope of the Regulation and if the clause is invalid, a Member State court will have

\footnotetext{
61 See Art. 37(3) and Recital 23 of the Commission's Proposal.

62 With respect to class actions, see Bariatti (2012), p. 328. With respect to personality rights, see Frigo (2012), p. 342.

63 Art. 45(1)(a) Brussel I bis as opposed to para. 3.1.1 of the Explanatory Memorandum accompanying the Proposal; see also Frigo (2012), p. 342.

64 Arts. 1(2)(d), 29(4) and 33(3) Brussels I bis; Recitals 11 and 20. See also the Explanatory Memorandum (1.2 and 3.1) of COM(2010) 748; Hess/Pfeiffer/Schlosser Heidelberg Report (2008), paras. 31-135.

65 See Art. 1(2)(d) Brussels I bis.

66 Convention on the Recognition and Enforcement of Foreign Arbitral Awards (New York, 1958) (the 'New York Convention').

67 See the Explanatory Statement in document A7-0320/2012 of 15 October 2012.

68 Van Houtte (2005); Dickinson (2011), p. 17; Kindler (2012).

69 See CJEU Case C-185/07 Allianz SpA and Generali Assicurazioni Generali SpA v. West Tankers Inc [2009] ECR I-663, which has sparked much debate. See also Consolo and Stella (2012); Harris and Lein (2012); Menétrey and Racine (2014).

70 Hess/Pfeiffer/Schlosser Report (2008).
} 
to determine its jurisdiction on the basis of Brussels I. $^{71}$ However, an arbitral tribunal is not precluded from granting an anti-suit injunction. ${ }^{72}$

Essentially, the problem with the demarcation of the exception is that arbitration is a procedural matter which is excluded from the scope of the Regulation, while the other exceptions (status and legal capacity, insolvency, social security, maintenance obligations and wills and succession ${ }^{73}$ ) relate to fields of substantive law. The proper demarcation is therefore that if the legal issue in question relates to the arbitration procedure, it is excluded. ${ }^{74}$ However, under a strict application of this logic, the court of the seat of arbitration should be allowed to issue an anti-suit injunction, which is not what the Court found.

Despite this controversy, it was in my opinion a wise choice not to amend the scope of the Regulation, as it would have increased uncertainty and grey zones. The EU was not able to regulate the entire field of arbitration and this is a good example of where infiltration could only be partial and confusing.

Turning to the European Account Preservation order one finds another example of an infiltration stopped by lack of consensus. The procedure for attaching assets in bank accounts in other EU Member States is very limited. It only concerns the blocking of funds, so that the creditor's rights are safeguarded; it only concerns preservation orders. ${ }^{75}$ The Regulation does not apply to attachment in execution of a judgment. The Regulation thus provides an alternative to preservation orders under national law. ${ }^{76}$ Such preservation orders are available as provisional measures under Brussels I bis ${ }^{77}$ which is the subject of the next section of this article.

The Service Regulation's scope is broader than that of most of the other Regulations discussed here. It applies only to the service of documents, but the range of documents that can fall under its ambit is very large. Even the title of the Regulation indicates a broad scope: it includes judicial and extrajudicial documents. While 'judicial documents' are reasonably clear and fit within the scope of the other Regulations in the area, the concept of 'extrajudicial documents' raised questions, which in turn produced case law by the Court of Justice. The Court has underlined the literal meaning of the phrase, including all sorts of documents whether or not they are connected to court proceedings. ${ }^{78}$

This section has shown that the scope of the Regulations is not always dictated by logic. EU law infiltrates civil procedure gradually but not systematically. The scope of legislation is often dependent on factors related to political compromise.

\footnotetext{
71 CJEU Case C-185/07 Allianz SpA and Generali Assicurazioni Generali SpA v. West Tankers Inc [2009] ECR I-663.

72 CJEU Case C-536/13 Gazprom, ECLI:EU:C:2015:316.

73 Art. 1(2) Brussels I bis.

74 CJEU Cases C-190/89 Rich v. Società Italiana Impianti [1991] ECR I-3855 and C-391/95 Van Uden Maritime v. Kommanditgesellschaft in Firma Deco-Line [1998] ECR I-7091.

75 Art. 1 European Account Preservation Order Regulation.

76 Art. 1(2) European Account Preservation Order Regulation.

77 Art. 35 Brussels I bis.

78 CJEU Case C-14/08 Roda Golf \& Beach Resort SL [2009] ECR I-5439; joined Cases C-226/13, C-245/13, C-247/13 and C-578/13 Fahnenbrock (and others), ECLI:EU:C:2015:383.
} 


\section{Provisional Measures}

The Regulations on jurisdiction and the recognition and enforcement of judgments all allow for provisional measures. The rules, however, provide little more than a possibility with some limitations. The Court of Justice of the EU has added some limitations. The Court has ruled that there must be a real connecting link between the dispute and the court granting the measures and that the measures must be provisional and reversible. $^{79}$

The Brussels II bis Regulation's rule has more built-in limitations. ${ }^{80}$ Urgency is an explicit requirement, while this is not the case under Brussels I bis. The Court of Justice of the EU has not yet ruled on this particular requirement, probably because the national laws of most Member States require urgency in order to have access to the available provisional measures. ${ }^{81}$

The provisional nature of the measures under Brussels II bis is reiterated by the fact that they automatically lapse when the court with jurisdiction on the merits issues appropriate measures. $^{82}$

The other Regulations follow the rule of Brussels I. $^{83}$ As the rules are worded almost identically, it seems logical that the interpretative case law by the Court of Justice of the EU also applies to these Regulations. However, one can only be certain of that when a question arises. The nature of provisional measures in maintenance matters is different from commercial matters and specific needs might arise.

Other than that, there is no EU harmonisation of the bases of jurisdiction for provisional measures. Neither is there a harmonised set of available measures. The provisions on provisional measures are merely permissive: they allow a digression from the normal framework of jurisdictional rules that the Regulations set up. ${ }^{84}$ If a case is provisional, urgent and has a real connecting link with the territory of the Member State in which the court is located, the court can base its jurisdiction on national law and temporarily ignore the EU's jurisdiction rules.

This diversity in available provisional measures caused problems at the stage that the Commission proposed to abolish exequatur. Of course, if measures issued on very broad national bases of jurisdiction could circulate freely throughout the EU without any need for exequatur, the entire system would be jeopardised. Litigants would be able to forum shop and get what they want where they want and then export as their needs or whims require. The answer was to exclude the exequaturfree circulation of provisional measures that were not issued by the court that has

\footnotetext{
79 CJEU Case C-391/95 Van Uden [1998] ECR I-7091 and Case C-99/96 Mietz. [1999] ECR I-2277.

80 Art. 20 Brussels II bis.

${ }^{81}$ I am not aware of any legal system that would allow provisional measures for reasons other than urgency. Legal systems impose this requirement as a filter to allow some cases into a fast lane. Allowing any case into the fast lane without any filter would lead to the fast lane no longer being fast.

82 Art. 20(2) Brussels II bis.

83 Art. 14 Maintenance Regulation; Art. 19 Succession Regulation.

${ }^{84}$ See also Borrás Report (1998), at paras. 58-59.
} 
jurisdiction on the merits. ${ }^{85}$ Such measures therefore have a territorial limitation. A party wishing the same provisional or protective measures in different Member States will have to request them in the various States, or request them in a court in the Member State that has jurisdiction over the merits of the dispute.

It once again becomes apparent that the infiltration of EU law in civil procedure is a chaotic affair, marred by compromise and practical hurdles.

\section{Recognition and Enforcement}

Guaranteeing easy recognition and enforcement in EU Member States of judgments issued in other Member States is the core of the EU civil procedure regime. This forms the raison d'être of the other rules. ${ }^{86}$ Roughly speaking, the EU Regulations facilitate recognition and the enforceability of judgments: they create the framework of the obligation to recognise and grant enforcement to foreign judgments. They also regulate which intermediate steps may be imposed in order to make a foreign judgment equal to a domestic judgment for purposes of enforcement. The actual enforcement (such as attaching assets), however, is still regulated nationally. This delineation seems logical if one takes into account the diversity of national enforcement procedures, authorities, requirements and exceptions. I will now discuss each of the phases in turn, pointing out that the delineation is not all that clear in practice.

\subsection{Recognition and Enforceability}

The recognition and enforcement regimes vary in the different Regulations. Three categories can be distinguished:

1. Easy exequatur. This is the standard regime under Brussels II bis and the Succession Regulation. It is also one of the regimes in the Maintenance Regulation: it applies if the judgment emanates from a court in a Member State which is not bound by the Hague Protocol on the Law Applicable to Maintenance Obligations. ${ }^{87}$ The Member States not bound by the Protocol are Denmark and the United Kingdom. ${ }^{88}$ 'Easy exequatur' means that there is an intermediary step between the initial judgment given in Member State A and the

\footnotetext{
85 See Art. 2 Brussels I bis, stating that the term 'judgment' excludes provisional and protective measures for purposes of the section on recognition and enforcement.

86 See Art. 81 of the Treaty on the Functioning of the European Union, referring to the principle of the mutual recognition of judgments and decisions as the basis for judicial cooperation in civil matters having cross-border implications. See also Meeusen (2007).

87 Hague Protocol of 23 November 2007 on the Law Applicable to Maintenance Obligations, available at http://www.hcch.net/index_en.php?act=conventions.text\&cid=133. This Protocol is incorporated in the Maintenance Regulation (see Art. 15) and thus in EU law: Council Decision of 30 November 2009 on the conclusion by the European Community of the Hague Protocol of 23 November 2007 on the Law Applicable to Maintenance Obligations, OJ L 331, 16 December 2009, p. 17.

${ }^{88}$ See Recitals 11 and 12 of the Council Decision to conclude the Protocol (n. 87 above).
} 
actual enforcement in Member State B. The intermediate step is a court procedure in Member State B to make the foreign judgment equivalent to a national judgment. The procedure is simplified, as it is unilateral ${ }^{89}$ and the grounds for refusal are limited. ${ }^{90}$ The exequatur court's powers are limited: it can neither review the substance of the case, ${ }^{91}$ nor second guess the basis of jurisdiction the court used ${ }^{92}$ nor re-assess the way in which it found the applicable law. ${ }^{93}$

2. Partial abolition of exequatur. This middle position is found in the Brussels I bis Regulation. After much talk of the abolition of exequatur, ${ }^{94}$ the compromise was that exequatur was in principle abolished, but that the judgment debtor may contest the enforcement of the judgment. This means that a judgment that falls under Brussels I bis has the same effect in all other Member States as it does in the Member State where it was granted. However, the judgment debtor can contest this by initiating a procedure to stop the exequatur. ${ }^{95}$ At this stage, the court will examine the grounds for refusal, but, as in the first regime discussed above, only the ground for refusal and nothing more. $^{96}$

3. Abolition of exequatur. This regime applies to the Maintenance Regulation for judgments issued by the courts of Member States bound by the Hague Protocol on the law applicable to maintenance obligations. ${ }^{97}$ It also exists for two welldefined situations under Brussels II bis, namely decisions on access rights and decisions to return abducted children after an initial non-return order. ${ }^{98}$ In these cases the judgment granted in a Member State has the same effect in all other Member States. Immediate enforcement is possible, and no intermediate step is

\footnotetext{
89 Arts. 28-32 Brussels II bis; Arts. 43-49 Succession Regulation; Arts. 26-31 Maintenance Regulation.

90 Arts. 22-23 Brussels II bis; Art. 40 Succession Regulation; Art. 24 Maintenance Regulation.

91 Art. 26 Brussels II bis; Art. 41 Succession Regulation; Art. 42 Maintenance Regulation.

92 Art. 24 Brussels II bis. This is not explicitly stated in the Succession and Maintenance Regulations, but is understood under the prohibition of a review as to the substance. As these Regulations contain completely unified rules on jurisdiction, the idea is that there will be no reason to refuse recognition and enforcement on this basis.

93 Art. 25 Brussels II bis. This is not explicitly stated in the Succession and Maintenance Regulations, but is understood under the prohibition of a review as to the substance. The Succession Regulation contains completely unified rules on the applicable law, and the idea is that there will be no reason to refuse recognition and enforcement on this basis. (The Maintenance Regulation does not contain unified rules on the applicable law for the Member States that fall under this exequatur regime.)

94 See the Commission's Proposal for a Regulation of 14 December 2010 on jurisdiction and the recognition and enforcement of judgments in civil and commercial matters (Recast), COM(2010) 748. See also Hess/Pfeiffer/Schlosser Heidelberg Report (2008); Arenas (2010); Cuniberti and Rueda (2011). 95 Art. 46 Brussels I bis.

96 Art. 45 Brussels I bis. At this stage the court may not consider grounds for refusing the actual enforcement that may exist under national law as permitted by Art. 41(2). This provision applies only at the stage of actual enforcement and includes matters such as set-off. See Kramer (2013).

97 Art. 17 Maintenance Regulation.

98 Arts. 40-42 Brussels II bis.
} 
required to make the judgment equal to a national judgment. Although this sounds rather efficient, it causes problems in practice. ${ }^{99}$

This third regime should be further divided into two sub-regimes. The first is where exequatur is no longer possible. Such is the case under the Maintenance Regulation. ${ }^{100}$ The judgment creditor can only turn to the enforcement authorities (be that a bailiff, the police or a juge d'exécution/beslagrechter). The second is where two alternative routes are open to the judgment creditor. $\mathrm{He}$ or she can choose whether to directly enforce or to get an exequatur order. ${ }^{101}$ This is the case under Brussels II bis. Although this might seem like a strange way to abolish exequatur, the residual availability of the exequatur procedure may be useful where a party faces practical difficulties. Such difficulties certainly exist at a time when national enforcement authorities are not yet imbued with the idea of directly enforcing foreign judgments. The combination of the previous Brussels I (No. 44/2001) and the European Enforcement Order (Regulation No. 805/2004 ${ }^{102}$ ) also falls in this category. The Enforcement Order Regulation provided a mechanism by which a court can issue a certificate for a judgment for which the claim is uncontested. The certificate functions as a visa which permits the judgment to circulate freely in the EU, without the need for a declaration of enforceability. In the sphere of civil and commercial matters, the creditor of an uncontested claim thus had a choice to obtain the certificate and directly enforce, or to apply for a declaration of enforceability.

Thus we see that the EU law of civil procedure is gradually abolishing exequatur. In this process, the exact current positions are very different in the various Regulations. Moreover, looking at two recent Regulations, Brussels I bis and Succession, it becomes apparent that the abolition of exequatur is not intensified with every new step. The Maintenance Regulation in fact goes the furthest in this regard while the Succession Regulation returned to an earlier system and Brussels I bis opted for a halfway solution. These Regulations all govern matters of civil law, but the exact extent of EU infiltration varies greatly.

\footnotetext{
99 The studies on Brussels II bis ordered by the Commission have not yet been published. The case law by the Court of Justice EU gives an indication that the abolition of exequatur does not function smoothly: see for instance CJEU Case C-195/08 PPU Rinau [2008] ECR-5271; Case C-211/10 PPU Povse v. Alpago [2010] ECR I-6673; Case C-491/10 PPU Aguirre Zarraga v. Pelz [2010] ECR I-14247.

100 Arts. 17-22 of the Maintenance Regulation provide no legal basis for requesting a declaration of enforceability. See also Couwenberg (2013), p. 192.

101 Art. 40 Brussels I bis, introducing the rules on the abolition of exequatur, explicitly mentions in para. 2 that ' $[\mathrm{t}] \mathrm{he}$ provisions of this Section shall not prevent a holder of parental responsibility from seeking recognition and enforcement of a judgment in accordance with the provisions in Sections 1 and 2 of this Chapter.' An illustration of this scenario is found in CJEU Case C-211/10 PPU Povse v. Alpago [2010] ECR I-6673.

102 Regulation (EC) No. 805/2004 of the European Parliament and of the Council of 21 April 2004 creating a European Enforcement Order for uncontested claims, OJ L 143, 30 April 2004, p. 15.
} 


\subsection{Actual Enforcement}

The Regulations leave the issue of actual enforcement in the hands of the Member States. In other words, the EU influence stops with the issuing of a judgment, or at the point when the judgment is made equivalent to a national judgment. For actual enforcement the principle of territoriality still reigns. ${ }^{103}$ Brussels I bis explicitly refers to national law for actual enforcement. ${ }^{104}$

This causes difficulties, as the procedures of enforcement differ vastly in the various Member States. To mention just a few examples where differences exist ${ }^{105}$ :

- the competent authorities,

- the involvement of judges,

- the access of the creditor to information about the debtor's assets,

- when and how attachment takes place,

- which assets are attachable,

- when the use of force is permitted,

- when penalties are issued,

- publication requirements prior to a sale in execution.

Again, the demarcation is not solid. Brussels I bis does impose some requirements for enforcement.

First, before actual enforcement is possible, the judgment must be enforceable in the country where it was issued. ${ }^{106}$ This is logical, as a judgment creditor cannot have more rights in the enforcing state than in the State where the judgment emanated. National laws differ on whether enforcement is possible when the judgment is subject to an appeal. In some States this is the case, while in other States the appeal suspends enforceability. In the States where enforceability is suspended, a further distinction is possible, i.e. whether or not the judgment can be declared enforceable by way of exception. While there is no harmonisation on this matter, the EU legislator has tried to patch up some of the problem areas. In this sense, the Maintenance Regulation provides that a court of origin may declare a judgment provisionally enforceable subject to appeal, even if this is not possible under the national law of that State. ${ }^{107}$ Again, we do not have a harmonised system, but haphazard and badly delimitated rules.

The Regulation then goes on to say that the enforcement must take place 'under the same conditions as a judgment given in the Member State addressed'. No harmonisation, but an attempt at the transposability of rights. However, this is immediately nuanced by the next paragraph, which allows the application of the

\footnotetext{
103 Brijs (2010), p. 63; de Leval (1998), p. 1.

104 Art. 41 Brussels I bis. See, with the same effect, Art. 47 Brussels II bis, Art. 41 Maintenance Regulation, Art. 46 Succession Regulation.

105 For a comparative survey of enforcement, see de Leval (1998). Although this survey is already dated, it gives a good idea of the difference that can exist between national systems.

106 Art. 41(1) Brussels I bis.

107 Art. 39 Maintenance Regulation.
} 
grounds for the refusal of Member State enforcement. ${ }^{108}$ These may not be incompatible with the Regulation's own grounds for the refusal of recognition. In this way a labyrinth of rights is created, rather than a neat division of tasks between the EU and the various pertinent national laws.

Various problems can arise, for instance the amount of detail that the initial judgment should contain in order to enable or facilitate enforcement. The form and the compulsory elements of the judgment is a matter of domestic civil procedure law. However, as these national rules have primarily been drawn up for the internal enforcement of judgments, they form a coherent system domestically, but not necessarily internationally. The amount of detail that a judgment contains largely depends on what is needed nationally: if a judge is involved at the enforcement stage, there is less need for detail. An example that has caused problems internationally is that of interests. In some countries, enforcement authorities do not have the power to enforce the part of the judgment on interests if these are not stated precisely in the judgment. In other States, judgments might contain only a reference to interests without an exact calculation. Brussels I bis attempted to resolve this issue by a specific section in the certificate, dealing in detail with interests. ${ }^{109}$

Another potential problem is when the ordered measures are not known in the State of enforcement. For this situation Brussels I bis contains a provision on adaptation. ${ }^{110}$ The rule is that the enforcing authority should then seek a measure 'which has equivalent effects attached to it and which pursues similar aims and interests'. This rule expects a high-level legal comparison of authorities (not only judges) and how it will work in practice remains to be seen.

\section{Systemic Hurdles for the Creation of a Logical Delineation}

After having assessed particular points of infiltration, the question arises how the EU legislator should tackle legislation in this area in the future. This question is difficult to answer, as its answer depends on two entirely different things. The first is the legislative goal: what is this legislation to achieve, how can and should it help individuals and corporations operating across borders? This goal includes various aspects of quality legislation, such as contributing to fairness and legal certainty. The second is the political reality. The making of EU legislation is complex. Various institutions are concerned, neutral (Commission), or representing political fractions (Parliament) or national interests (Council). EU legislation can only infiltrate as deep as these legislative bodies permit. In itself this is a good thing, because the institutions guarantee the democratic legitimacy of the EU. It can, however, as the previous sections of this article have shown, lead to disjunctive legislation.

\footnotetext{
108 Art. 41(2) Brussels I bis.

109 See 4.6.1.5 and 4.7.4 of Annex I to Brussels I bis (Certificate concerning a judgment in civil and commercial matters). These sections make provision for the court of origin to fill in the exact amount of interests, or the rate of calculation plus the dates from and until when interests are due.

110 Art. 54 Brussels I bis.
} 
The initiators of legislation (the Commission, generally speaking) may be able to answer to the legislative goal quite comprehensively, but when faced with political difficulties, they may have to back down, rather on portions of the legislation than on everything.

The purpose of this last section of the article is not to discuss the entire political process of legislation, nor to theorise on the nature of legislation in the sphere of international procedure. ${ }^{111}$ Rather, I will discuss two potential (albeit very different) hurdles for harmonious legislation, namely the principles of subsidiarity and proportionality, and enhanced cooperation.

\subsection{Subsidiarity and Proportionality}

The principles of subsidiarity and proportionality govern the use of EU competences. ${ }^{112}$ 'Subsidiarity' means that the EU can only enact legislation to the extent that the goals of the action can better be achieved by the EU and not at national or local levels. ${ }^{113}$ 'Proportionality' means that the EU action should not exceed what is necessary to achieve the Treaty objectives. ${ }^{114}$ The underlying idea of both principles is that decisions must be taken as closely as possible to the citizen. ${ }^{115}$ Whenever the Commission proposes legislation, it should include a substantiated statement on subsidiarity and on proportionality. ${ }^{116}$

In the domain of international procedure, it is relatively easy to justify that a particular measure conforms to the principles of subsidiarity and proportionality. For instance, measures on abolishing exequatur can be better achieved by EU legislation, imposing the same requirements across the EU. ${ }^{117}$ At the same time, the justification is sometimes meagre. In the Explanatory Memorandum to the Proposal for the Succession Regulation, the Commission for instance simply said that the objectives of the proposal could only be met by common rules that are identical in order to guarantee legal certainty and predictability. ${ }^{118}$ The Commission justified the adherence to the principle of proportionality by saying that the Regulation does not propose uniform law on property or succession. This way of justifying could apply to all fields of private international law (thus including international

\footnotetext{
111 On the last topic, see Fallon (2009); Fallon and Kruger (2012-2013).

112 Art. 5(1) Treaty on European Union states: 'The limits of Union competences are governed by the principle of conferral. The use of Union competences is governed by the principles of subsidiarity and proportionality'.

113 Art. 5(3) Treaty on European Union.

114 Art. 5(4) Treaty on European Union.

115 Protocol No. 2 (of the Treaty on European Union) on the Application of the Principles of Subsidiarity and Proportionality.

116 Art. 5 of Protocol No. 2.

117 See the justification by the Commission in its Proposal for the Recast of Brussels I, COM(2010) 748.

118 Para. 3.2 on Subsidiarity in the Explanatory Memorandum to the Proposal for a Regulation of the European Parliament and of the Council on jurisdiction, applicable law, recognition and enforcement of decisions and authentic instruments in matters of succession and the creation of a European Certificate of Succession, COM(2009) 154 final - 2009/0157 (COD).
} 
procedure), as long as the legislator stops short of unifying substantive domestic law.

However, respecting the principles of subsidiarity and proportionality is not always that straightforward. This is apparent in the uniform procedures. The Small Claims Procedure, the Payment Order and the Account Preservation Order are all limited to cross-border cases, due to the principles of subsidiarity and proportionality. The result is that the procedures are only available to cross-border traders or consumers. We can thus see how the subsidiarity principle limits coherence in international procedure.

Also in other domains, some aspects are left out due to subsidiarity considerations. This is for instance the case with arbitration, where the Parliament pointed out that the New York Convention already exists and works well. ${ }^{119}$ Brussels II bis underlines the importance of hearing the child, but explicitly refrains from modifying national procedures. ${ }^{120}$ The differences in when children are heard are so great that they have an impact on the functioning of the international system. Subsidiarity again limits coherence.

\subsection{Enhanced Cooperation?}

The second potential hurdle is the legislative possibility of enhanced cooperation. ${ }^{121}$ When the legislative process fails, for instance when unanimity cannot be reached in the Council in a field where this is required, ${ }^{122}$ enhanced cooperation provides the possibility for some Member States to continue with the legislation while the others remain unbound.

Until recently EU States have not taken this route in the field of international civil procedure, even though this has happened in the field of applicable law. ${ }^{123}$ However, in March 2016 the European Commission adopted two proposals for enhanced cooperation: one on matrimonial property ${ }^{124}$ and one on the property consequences of registered partnerships. ${ }^{125}$ These regulations, like the Maintenance and Succession Regulations, contain sections on jurisdiction and on the recognition and enforcement of judgments.

\footnotetext{
119 See Sect. 2.3 above.

120 Recital 19 Brussels II bis.

121 Art. 20 Treaty on European Union.

122 This is the case for measures in international family law, Art. 81(3) Treaty on the Functioning of the European Union.

123 Regulation (EU) No. 1259/2010 of 20 December 2010 implementing enhanced cooperation in the area of the law applicable to divorce and legal separation ('Rome III'), OJ L 199, 31 July 2007, p. 40. This Regulation is in force in Austria, Belgium, Bulgaria, France, Germany, Greece, Hungary, Italy, Latvia, Lithuania, Luxembourg, Malta, Portugal, Romania, Slovenia and Spain.

124 Proposal for a Council Regulation on jurisdiction, applicable law and the recognition and enforcement of decisions in matters of matrimonial property regimes, of 2 March 2016, COM(2016) 106.

125 Proposal for a Council Regulation on jurisdiction, applicable law and the recognition and enforcement of decisions in matters of the property consequences of registered partnerships, of 2 March 2016, COM(2016) 107.
} 
Moreover, although enhanced cooperation is scarce, three Member States have a peculiar position in this matter, so that there is no complete uniformity in the EU. Denmark does not participate in this chapter of EU law. ${ }^{126}$ However, it is able to circumvent this non-participation by way of individual treaties with the EU. ${ }^{127}$ Ireland and the United Kingdom occupy a fence-sitting position according to which they can decide for every piece of legislation whether they will opt in or out. ${ }^{128}$

These ways in which legislation can be in force in some Member States but not in others create grey areas and incoherence. While the opt-in/opt-out system can be deplored, it will be difficult to change. Other than that, Member States should not use the enhanced cooperation mechanism lightly if at all.

\section{Conclusion}

Certain things have proved too difficult to harmonise, at least up until now. The fact that harmonisation is incomplete is in itself not problematic: the Member States have functioning legal systems and rules on civil procedure. However, what we have seen over the past years is an increasing incoherent harmonisation. There is no straight and logical line between the domains governed by EU law and the domains governed by national law. This incoherence causes confusion for practitioners and judges. In the worst cases, it even risks leading to mistakes in the delivery of justice.

What should have become clear to the reader by now is the lack of coherence. It is not possible to state clearly which parts of civil procedure are and which parts are not governed by EU law. This is largely the result of political compromises and particular hurdles in the legislative process.

So what is the current state of EU infiltration in civil procedure? This article has shown some of the problems in the delimitation, while providing some understanding of how they were caused.

The legislator should take caution in creating coherent legislative frameworks, as complex rules lead to mistakes by those applying the law and to a lack of legal certainty. This increases the costs for consumers of the law. This concern should be taken to heart in negotiations, even if that might mean leaving a particular area unregulated. Partial legislation by way of compromises and enhanced cooperation should rather be avoided. Then it will become easier to keep our balance when treading between national and EU rules on international civil procedure.

\footnotetext{
126 See Protocol No. 22 to the Treaty on European Union on the Position of Denmark. This Protocol allows Denmark to convert its position into the opt-in/opt-out position that the United Kingdom and Ireland have. The Danes held a referendum on the issue on 3 December 2015, but $53.1 \%$ voted not to change the current position: uk.reuters.com, 3 December 2015.

127 Such treaties exist for the Brussels I (bis), the Service and Maintenance Regulations.

128 See Protocol No. 21 to the Treaty on European Union on the Position of the United Kingdom and Ireland in respect of the area of Freedom, Security and Justice. These two Member States have so far opted into most of the legislation in the field of international civil procedure. They did not opt into the Succession Regulation (Recital 82). The Maintenance Regulation is only partially applicable in the United Kingdom (i.e. the procedural parts, but not the part on the applicable law). The United Kingdom opted out of the European Account Preservation Order (Recital 50).
} 


\section{References}

Arenas R (2010) Abolition of exequatur: problems and solutions. Mutual recognition, mutual trust and recognition of foreign documents: too many words in the sea. Yearb Priv Int Law 12:351-375

Bariatti S (2012) Recognition and enforcement in the EU of judicial decisions rendered upon class actions: the case of U.E. and Dutch judgments. In: Pocar F, Viarengo I, Villata FC (eds) Recasting Brussels I. Cedam, Milan, pp 319-339

Baumgartner SP (2012) Changes in the European Union's regime of recognizing and enforcing foreign judgments and transnational litigation in the United States. Southwest J Int Law 18:567-594

Borrás A (1998) Explanatory report on the Convention, drawn up on the basis of Article K.3 of the Treaty on European Union, on jurisdiction and the recognition and enforcement of judgments in matrimonial matters. OJ C 221, 16 July 1998, p 27

Borrás A (2012) The application of the Brussels I Regulation to defendants domiciled in third states: from the EGPIL to the Commission Proposal. In: Lein E (ed) The Brussels I recast uncovered. British Institute of International and Comparative Law, London, pp 57-74

Briggs A (2013) The conflict of laws, 3rd edn. Oxford University Press, Oxford

Brijs S (2010) Nieuwe Europese uitvoerbare titels: wie ziet het bos nog door de bomen? In: Dirix E (ed) Recente ontwikkelingen insolventierecht, beslagrecht en zekerheden (Themis reeks). Die Keure, Bruges, pp 59-96

Clarkson CMV, Hill J (2011) The conflict of laws, 4th edn. Oxford University Press, Oxford

Consolo C, Stella M (2012) Brussels I Regulation amendment proposals and arbitration. In: Pocar F, Viarengo I, Villata FC (eds) Recasting Brussels I. Cedam, Milan, pp 37-56

Couwenberg I (2013) Brussel I-Vo: quo vadis exequatur? In: Centrum voor Beroepsvervolmaking in de Rechten (ed) CBR Jaarboek 2012-2013. Intersentia, Antwerp, pp 143-210

Cuniberti G, Rueda I (2011) Abolition of exequatur addressing the Commission's concerns. Rabels Z 75:286-316

De Leval G (1998) Aperçu du droit de l'exécution dans les états membres de l'Union Européenne. L'Huissier de Justice/De Gerechtsdeurwaarder, pp 1-27 (this publication is bilingual French/Dutch)

Dickinson A (2011) The Proposal for a Regulation of the European Parliament and of the Council on Jurisdiction and the Recognition and Enforcement of Judgments in Civil and Commercial Matters (Recast) ('Brussels I bis' Regulation), Note for Directorate General for Internal Policies. Policy Department C: Citizen's Rights and Constitutional Affairs. http://www.europarl.europa.eu/RegData/ etudes/note/join/2011/453200/IPOL-JURI_NT(2011)453200_EN.pdf. Accessed 1 Feb 2016

Fallon M (2009) L'européanisation du droit international privé: une codification en marche. In: Erauw J, Taelman P (eds) Nieuw internationaal privaatrecht: meer Europees, meer globaal. Kluwer, Mechelen

Fallon M, Kruger T (2012-2013) The spatial scope of the EU's rules on jurisdiction and enforcement of judgments: from bilateral modus to unilateral universality? Yearb Priv Int Law 14:1-35

Fentiman R (2005) National law and the European jurisdiction regime. In: Nuyts A, Watté N (eds) International civil litigation in Europe and relations with third states. Bruylant, Brussels, pp 83-128

Francq S (2014) Les clauses d'élection de for dans le nouveau règlement Bruxelles I bis. In: Guinchard E (ed) Le nouveau règlement Bruxelles II bis. Bruylant, Brussels, pp 107-146

Franzina P (2014) L'universalisation partielle du régime Européen de la compétence en matière civile et commerciale dans le règlement Bruxelles I bis: une mise en perspective. In: Guinchard E (ed) Le nouveau règlement Bruxelles II bis. Bruylant, Brussels, pp 39-82

Frigo M (2012) Recognition and enforcement of judgments on matters relating to personality rights and the recast proposal of the Brussels I Regulation. In: Pocar F, Viarengo I, Villata FC (eds) Recasting Brussels I. Cedam, Milan, pp 341-352

Harris J, Lein E (2012) A neverending story? Arbitration and Brussels I: the recast. In: Lein E (ed) The Brussels I recast uncovered. British Institute of International and Comparative Law, London, pp 31-56

Hausmann R (2012) The scope of the Brussels I Regulation. In: Pocar F, Viarengo I, Villata FC (eds) Recasting Brussels I. Cedam, Milan, pp 3-27

Hess B, Pfeiffer T, Schlosser P (2008) The Brussels I-Regulation (EC) No 44/2001. CH Beck, Munich (also known as the 'Heidelberg Report'). http://ec.europa.eu/civiljustice/news/docs/study_ application_brussels_1_en.pdf. Accessed 2 Feb 2016 
Kindler P (2012) Torpedo actions and the interface between Brussels I and international commercial arbitration. In: Pocar F, Viarengo I, Villata FC (eds) Recasting Brussels I. Cedam, Milan, pp 57-70

Kramer X (2013) Cross-border enforcement and the Brussels I-bis Regulation: towards a new balance between mutual trust and national control over fundamental rights. Neth Int Law Rev 30:343-373

Kruger T (2008) Civil jurisdiction rules of the EU and their impact on third states. Oxford University Press, Oxford

Layton A (2012) The Brussels I Regulation in the international legal order: some reflections on reflectiveness. In: Lein E (ed) The Brussels I recast uncovered. British Institute of International and Comparative Law, London, pp 75-81

Meeusen J (2007) Instrumentalisation of private international law in the European Union: towards a European conflicts revolution? Eur J Migr Law 9:287-305

Menétrey M, Racine J-B (2014) L'arbitrage et le règlement Bruxelles I bis. In: Guinchard E (ed) Le nouveau règlement Bruxelles II bis. Bruylant, Brussels, pp 13-38

Nadelmann KH (1967) Jurisdictionally improper fora in treaties on recognition and enforcement of judgments. The Common Market draft. Columbia Law Rev 67:995-1023

Nuyts A (2007) Study on residual jurisdiction (review of the Member States' rules concerning the 'residual jurisdiction' of their courts in civil and commercial matters pursuant to the Brussels I and II Regulations). http://ec.europa.eu/civiljustice/news/docs/study_residual_jurisdiction_en.pdf. Accessed 2 Feb 2016

Nuyts A, Watté N (eds) (2005) International civil litigation in Europe and relations with third states. Bruylant, Brussels

Rogerson P (2012) Lis pendens and third states: the Commission's proposed changes to the Brussels I Regulation. In: Lein E (ed) The Brussels I recast uncovered. British Institute of International and Comparative Law, London, pp 103-124

Van Houtte H (2005) Why not include arbitration in the Brussels Jurisdiction Regulation? Arbitr Int 21:509-522

Von Mehren AT (1981) Recognition and enforcement of sister-state judgments: reflection on general theory and current practice in the European Economic Community and the United States. Columbia Law Rev 81:1044-1060 